Original Research Paper

\title{
Chemical Composition, Antibacterial and in vitro Anti- Inflammatory Potentials of Essential Oils from Different Plant Parts of Moringa oleifera Lam
}

\author{
Gloria Aderonke Otunola and Anthony Jide Afolayan \\ Medicinal Plants and Economic Development (MPED) Research Centre, \\ Department of Botany, University of Fort Hare, Alice 5700, South Africa
}

\author{
Article history \\ Received: 21-05-2018 \\ Revised: 17-07-2018 \\ Accepted: 07-08-2018 \\ Corresponding Author: \\ Gloria Aderonke Otunola \\ Medicinal Plants and Economic \\ Development (MPED) \\ Research Centre, Department of \\ Botany, University of Fort \\ Hare, South Africa \\ Email: gotunola@ufh.ac.za \\ adeglo2004@gmail.com
}

\begin{abstract}
The chemical constituents, antibacterial, protection against protein denaturation and membrane stabilization activities of essential oils from flowers, leaves, seeds, bark and roots of M. oleifera were investigated. Of the eight bacterial strains tested, only the growths of four strains were inhibited by the essential oils. The oils from the flowers and seeds were the most active with MIC: $1.25 \mathrm{mg} / \mathrm{mL}$ each against $P$. vulgaris and $K$. pneumoniae respectively. All tested concentrations of M. oleifera essential oils showed high inhibition of protein denaturation $\left(\mathrm{IC}_{50} 0.2 \mathrm{mg} / \mathrm{mL}\right)$ and high membrane stability $\left(\mathrm{IC}_{50}:<0.1 \mathrm{mg} / \mathrm{mL}\right.$ ) compared to Diclofenac. The essential oils were dominated by eicosane $(20.93 \%, 17.12 \%$ and $21.59 \%)$ in flowers, leaves and seeds respectively; naphthalene (18.40\%) in bark and benzene isothiocyanato methyl $(35.83 \%)$ in the roots. The results revealed that essential oils from different plant parts of M. oleifera could be explored as potential candidates with alternative or complementary potentials for combating drug resistant bacteria and inflammation.
\end{abstract}

Keywords: Antibacterial Activity, Bioactive Constituents, Essential Oil, Membrane Stability, Moringa oleifera, Protein Denaturation

\section{Introduction}

Moringa oleifera is an ancient tree that is traditionally renowned for its numerous nutritional and pharmacological properties. $M$. oleifera belongs to the Moringaceae family, with 12 other species and although originally from India, it can now be found growing world-wide (Fahey, 2005; Price, 2007).

Nutritionally, the leaves are rich sources of macroand micro-nutrients. According to Fahey (2005) the leaves are richer in vitamins $\mathrm{A}$ and $\mathrm{C}$, calcium, potassium and protein than most conventional sources. Traditionally, all the different parts of the plant are consumed as vegetables and several information of the nutritional properties have been reported (Maponga and Monera (2010; Patel et al., 2010; Amrutia et al., 2011). Pharmacologically, $M$. oleifera plant parts have been credited with therapeutic properties against hypertension, convulsions, diabetes, cancer, inflammation, liver diseases, gastric ulcers and skin diseases (Pandey, 2012; Bakre et al., 2013). The crude, supernatant, residue and dialyzed seed extract have antimicrobial action (Jabeen et al., 2008), while the aqueous and ethanol extracts of the seeds have also been reported to possess antibacterial effect (Vieira et al., 2010). In addition, essential oil components of Moringa leaf (Kuben and Roger, 2011; Moyo et al., 2013), seed (Chuang et al., 2007) and root (petroleum ether) extract (Mukunzi et al., 2011) have been reported.

Inflammation is the cellular response to injury; and a complex cascade of reactions including increased vascular permeability, protein denaturation and membrane alterations, as well as the accumulation of cells and exudates in irritated tissues to protect and prevent further damage (Umapathy et al., 2010; Padmanabhan and Jangle, 2012; Osman et al., 2016). Several models have been used for evaluating the antiinflammatory potentials of plant extracts in vivo and in vitro. However, protein denaturation assay and erythrocyte membrane stability are the two mostly used assays for in vitro studies.

Denatured proteins lose their biological potency in vivo and become inflammatory mediators (Khan et al., 2015), which cause inflammation through the production of auto antigens and increased activity of macrophages 
(Tatiya and Saluja, 2011). Inflammation can be prevented by stabilizing the lysosomal membrane, since damage to the membrane will release lysosomal enzymes that produce diverse disorders related inflammation. Erythrocytes membranes structurally resemble lysosomal membranes; therefore, preventing the breakdown of the erythrocyte membrane is also often used as a measure for estimating the anti-inflammatory potentials of plant extracts in vitro (Omale and Okafor, 2008).

Phytochemicals possessing anti-inflammatory properties have been used traditionally over time for the treatment of inflammatory conditions such as fevers, pain, migraine and arthritis. Subsequently, extracts from food and food products which have anti-inflammatory actions are of great interest (Yua et al., 2006).

Moringa oleifera essential oils have exhibited in vitro anti-oxidant, anti-microbial, anti-hypertensive, anticancer, anti-tubercular and anti-inflammatory activities (Mishra et al., 2011; Pandey, 2012; Bakre et al., 2013); and also contains many bioactive constituents (Chuang et al., 2007; Moyo et al., 2013). The continuous search for safe, cheap and affordable treatments for various ailments, especially those caused by resistant microbial pathogens and inflammation, has led to investigations for bioactive molecules from essential oils from different parts of many plant species. According to Vieira et al. (2010) multi-drug resistant microbial strains is an increasing health concern globally, which justifies the current search for novel antimicrobial and antiinflammatory agents.

Even though several reports on Moringa oleifera abound in literature, the constituents of the essential oil of the various parts, their antibacterial and anti-inflammatory potentials still remain unrecorded. Therefore, this study aimed at evaluating the composition, antibacterial and anti-inflammatory properties of essential oils from different parts of Moringa oleifera.

\section{Materials and Methods}

\section{Plant Materials}

Different parts of Moringa oleifera Lam. were collected in clean plastic containers from the University of Ilorin Moringa Plantation, Nigeria in January 2014. The parts were cleaned and oven-dried $\left(40^{\circ} \mathrm{C}, 72 \mathrm{~h}\right)$, separately packed into clean ice-packed plastic containers, then transported to the MPED-RNA, UFH, South Africa; where specimens were deposited at the Giffen Herbarium of the University.

\section{Extraction of Essential Oils}

The Solvent Free Microwave Extractor was used. One hundred gram of each plant part was separately weighed into the reactor of an automatic Milestone DryDIST 2004, Bergamo, Italy, microwave apparatus and individually extracted without water or solvent.
Homogenous microwave energy distribution in the reactor was ensured with a microwave multimode reactor having twin magnetron $(2800 \mathrm{~W}, 2450 \mathrm{MHz})$ and maximum delivery power of $1000 \mathrm{~W}$ in $10 \mathrm{~W}$ increments and a rotating microwave diffuser. A shielded Thermocouple (ATC-300) inserted directly into the corresponding container was used to monitor the temperature, while a feedback to the microwave power regulator, controlled the temperature (initial temperature of $20^{\circ} \mathrm{C}$, increased at $7.5^{\circ} \mathrm{C} / \mathrm{min}$ up to $100^{\circ} \mathrm{C}$ ) before essential oil extraction for $10 \mathrm{~min}$. The total extraction process was $30 \mathrm{~min}$ and the temperature decreased at a rate of $7.0^{\circ} \mathrm{C} / \mathrm{min}$ until $30^{\circ} \mathrm{C}$ was reached. $\mathrm{N}$-hexane $(1.0$ $\mathrm{mL}$ ) was used to retain the extracted oil in the collector column. Yields were calculated and the oils stored in amber essential oil bottles at $4{ }^{\circ} \mathrm{C}$ prior until needed.

\section{Essential Oils Analysis}

Gas Chromatography-Mass Spectrometry (GC-MS) separation of the oils was carried out in an Agilent 7890B GC coupled to an Agilent 5977A mass selective detector and an Agilent ChemStation data system. The machine was equipped with a Zebron-5MS column [ZB-5MS 30m $\times 0.25$ $\mathrm{mm} 5 \%$-phenyl methyl polysiloxane capillary column, film thickness $(0.25 \mu \mathrm{m})]$; injector temperature $280^{\circ} \mathrm{C}$ and source temperature $280^{\circ} \mathrm{C}$. Initial oven temperature was $70^{\circ} \mathrm{C}$ for $15 \mathrm{~min}$; increased at $3 \mathrm{~min}$ to $120^{\circ} \mathrm{C}$, ramp at $10^{\circ} \mathrm{C} / \mathrm{min}$ to $180^{\circ} \mathrm{C}$, then ramp at $20^{\circ} \mathrm{C} / \mathrm{min}$ to $270^{\circ} \mathrm{C}$ for 3 minutes. Helium at a flow rate of $2 \mathrm{~mL} / \mathrm{min}$ was used as the carrier gas. The sample injected into the machine was $1 \mu \mathrm{L}$ using splitless injection technique. The various constituents were identified by comparing their mass spectra, retention indices using commercial libraries (NIST2014 GC-MS) and with those available in literature (Adams, 2007) as well as using the $\mathrm{C}_{8}-\mathrm{C}_{20}$ alkane standards.

\section{Antimicrobial Assays}

\section{Microbial Strains and Media}

The essential oil samples were screened against Enterococcus faecalis ATCC 29212, Streptococcus pyogenes, Pseudomonas aeruginosa ATCC 19582, Serratia marcescens ATCC 9986, Shigella flexneri KZN, Proteus vulgaris, Klebsiella pneumonia ATCC 4352 and Staphylococcus aureus. Sabouraud Dextrose Agar (SDA) and Broth (SDB) were prepared following manufacturer's instructions. The agar was dissolved in de-ionised water and sterilized by autoclaving for $15 \mathrm{~min}$ at $121^{\circ} \mathrm{C}$. Bacterial strains were kept on SDA plates at $4^{\circ} \mathrm{C}$, inoculums were prepared by diluting cell mass in $0.85 \%$ sodium chloride solution, adjusted to 0.5 McFarland standards and confirmed by measuring at 580 $\mathrm{nm}$ in a spectrophotometer. Final dilution of the cell suspensions in broth $(1: 100)$ gave approximate inoculum of $10^{4} \mathrm{CFUmL}^{-1}$ compared with McFarland standard. 


\section{Susceptibility Assays}

Antibacterial activities were evaluated using agar diffusion and micro dilution methods against the selected bacteria.

Susceptibility was determined by agar well diffusion technique. Agar plates were spread with $100 \mu \mathrm{L}$ of 0.5 McFarland solutions of the bacterial strain cultures in $0.85 \%$ Sterile Distilled Water (SDW). A cooled flamed cork borer $(5 \mathrm{~mm})$ was used to bore four wells in each plate and the agar plugs were removed using a sterile needle. 50 $\mu \mathrm{L}$ of the positive control drug Ciprofloxacin, $(0.0125$ $\mathrm{mg} / \mathrm{mL}$ ) and $50 \mathrm{mg} / \mathrm{mL}$ of nutrient broth (negative control) were added into the first and second wells, while into the remaining wells, $50 \mathrm{mg} / \mathrm{mL}$ of the essential oils dissolved in DMSO were added respectively, the culture plates were then incubated for $24 \mathrm{~h}$ at $37^{\circ} \mathrm{C}$. The diameter of clear zone around each well, indicating the activity of the plant extract against the organisms, was measured in $\mathrm{mm}$.

\section{Minimum Inhibitory Concentration (MIC)}

The Minimum Inhibitory Concentrations (MIC) of the essential oils were determined using 96-well microplates by the broth micro dilution method (Otang et al., 2012). Sterile distilled water $(120 \mu \mathrm{L})$ was added into each well of the first $(\mathrm{A})$ and last $(\mathrm{H})$ rows as well as wells of the last column. Then, $120 \mu \mathrm{L}$ of Nutrient Broth (NB) was added into each well of the second row (B). $150 \mu \mathrm{L}$ of NB was added into the remaining wells of the first column, $100 \mu \mathrm{L}$ into the rest of the wells from the second column rightward; fifty microliters of the essential oils was then added into the third well of the first column while $50 \mu \mathrm{L}$ of the positive (Amoxicillin) and negative control (SDW) were separately added into the remaining wells of the first column. Serial dilutions of the samples (essential oils or antibiotics) gave concentrations ranging from 0.005 to 5 $\mathrm{mg} / \mathrm{mL}$. Subsequently, $20 \mu \mathrm{L}$ of 0.5 bacterial suspensions was inoculated into the wells except those which contained SDW. Growth of bacteria before and after incubation was measured at $620 \mathrm{~nm}$ with an automatic microplate reader (SynergyMx BiotekR, USA). The lowest concentration of the test agent at which $50 \%$ bacterial growth was inhibited is the MIC. The differences between the absorbances of test wells and control wells that contained the broth and antimicrobial agent alone without the test bacteria was calculated as the growth rate.

\section{In-Vitro Anti-Inflammatory Activity}

\section{Protein Denaturation}

Bovine Serum Albumin (BSA) was used to determine the inhibition of protein denaturation (Murugan and Parimelazhagan, 2014). To the reaction mixture made up of $0.45 \mathrm{~mL}$ bovine serum albumin $(5 \% \mathrm{w} / \mathrm{v}, \mathrm{pH} 6.3)$ and $0.05 \mathrm{~mL}$ of distilled water, was added $1000 \mu \mathrm{g}$ of the essential oils from M. oleifera parts ( $\mathrm{mg} / \mathrm{ml}$ of DMSO), incubated for $30 \mathrm{~min}$ at $37^{\circ} \mathrm{C}$ and then heated at $57^{\circ} \mathrm{C}$ for $5 \mathrm{~min}$. The samples were cooled and $2.5 \mathrm{~mL}$ of phosphate buffer solution was added and the absorbance measured at $600 \mathrm{~nm}$. For negative control, $0.05 \mathrm{~mL}$ distilled water and $0.45 \mathrm{~mL}$ of bovine serum albumin was used, while Diclofenac was used as the reference drug. Inhibition of protein denaturation was calculated as:

Inhibition of protein denaturation $(\%)=[\mathrm{Abs}$ control- Abs Sample/Abs Control] $\times 100$

\section{Membrane Stabilization Assay}

Hypotonic solution-induced rat erythrocyte haemolysis was used to assess the membrane stabilizing activity of the essential oils. Rat erythrocyte cells were prepared as described previously (Oyedapo et al., 2010). Briefly, whole blood was obtained with heparinized syringes from a rat through cardiac puncture. The blood was washed three times with isotonic buffered saline solution at $\mathrm{pH} 7.4$ and centrifuged each time for $10 \mathrm{~min}$ at13000 rpm to obtain the stock erythrocytes (red blood cells). For the membrane stabilizing assay, the test sample consisted of essential oil or standard drug at concentrations ranging from 0.1 to $0.5 \mathrm{mg} / \mathrm{mL}$, plus stock erythrocyte suspension $(0.5 \mathrm{~mL}$, mixed with $5 \mathrm{~mL}$ of hypotonic solution $(50 \mathrm{mM} \mathrm{NaCl})$ in $10 \mathrm{mM}$ sodium phosphate buffered saline (pH 7.4). The control consisted of $0.5 \mathrm{~mL}$ of $\mathrm{RBC}$ mixed with hypotonicbuffered saline solution alone. The mixtures were incubated for $10 \mathrm{~min}$ at room temperature, centrifuged at $13000 \mathrm{rpm}$ for $10 \mathrm{~min}$ and absorbance of the supernatant was measured at $540 \mathrm{~nm}$. The percentage inhibition of haemolysis or membrane stabilization was calculated as:

$$
\% \text { Inhibition of haemolysis }=100 \times[\mathrm{OD} 1-\mathrm{OD} 2 / \mathrm{OD} 1]
$$

where, OD1 is the optical density of hypotonic-buffered saline solution alone and OD2 is the optical density of test sample in hypotonic solution. Diclofenac was used as the standard drug.

\section{Statistical Analysis}

The data were expressed as mean values \pm standard deviation of three replicates and were subjected to Analysis of Variance (ANOVA). Means were considered significant at $\mathrm{p}<0.05$. All analyses were done using MINITAB student version 12 for Windows software.

\section{Results}

\section{Chemical Composition}

The essential oils were obtained separately by solvent free microwave extraction method from the dried 
flowers, leaves, seeds, barks and roots of Moringa oleifera. The oil yields ranged from $0.3 \%$ in the seed to $3.6 \%$ in the leaves (Fig. 1). The composition and retention indices of the essential oils from different parts of Moringa oleifera are presented in Table 1.

A total of 47 compounds, making up $90.35 \%, 78.99 \%$, $92.77 \%, 96.59 \%$ and $99.99 \%$ from the flowers, leaves, seeds, barks and roots respectively were identified. Eicosane was the major component $(20.93 \%, 17.12 \%$ and $21.59 \%$ ) of the oils from the flowers, leaves and seeds respectively, while the oils from the barks and roots had naphthalene (18.40\%) and benzene isothiocyanato methyl $(35.83 \%)$ as the main components.

Table 1: Chemical composition (\%) of essential oils extracted from the different plant parts of $M$. oleifera

\begin{tabular}{|c|c|c|c|c|c|c|}
\hline Compound & RI & Flowers & Leaves & Seeds & Barks & Roots \\
\hline Trans-2,7-dimethyl-3,6-octadien-2-ol & 710 & - & 0.68 & - & 3.60 & - \\
\hline Benzaldehyde & 737 & - & - & 0.66 & 7.14 & 13.43 \\
\hline$\alpha$-thujone & 834 & - & - & - & 2.86 & - \\
\hline Eucalyptol & 949 & 0.58 & 1.30 & 0.87 & 8.06 & - \\
\hline Nonanal & 966 & 3.5 & 1.89 & 2.24 & 10.36 & - \\
\hline Benzyl nitrile & 993 & - & - & - & 4.65 & 14.17 \\
\hline 2-Bornanone (Camphor) & 996 & 3.94 & 2.65 & 3.97 & 10.65 & - \\
\hline Benzene acetaldehyde & 1002 & 0.49 & 1.27 & 0.61 & 5.72 & - \\
\hline 2-Isopropoxyphenol & 1005 & - & - & 2.49 & 9.68 & - \\
\hline Terpinen-4-ol & 1007 & 0.42 & - & - & - & - \\
\hline Naphthalene & 1011 & - & - & 13.41 & 18.40 & - \\
\hline$\alpha$-Terpineol & 1012 & 0.36 & 0.37 & - & - & - \\
\hline Estragole & 1013 & - & - & 1.03 & - & - \\
\hline Anethole & 1022 & - & - & 1.51 & 5.95 & - \\
\hline Benzene, isothiocyanato methyl & 1046 & - & - & - & - & 35.83 \\
\hline Methyl eugenol & 1086 & 0.66 & 1.14 & 2.72 & - & 1.04 \\
\hline Heptadecane & 1092 & 1.56 & 1.04 & 1.37 & - & - \\
\hline 2-Pentadecanone, 6,10,14-trimethyl & 1100 & 1.65 & 1.00 & 3.02 & - & 0.90 \\
\hline Megastigmatrienone & 1101 & 0.56 & - & - & - & - \\
\hline Nonadecane & 1105 & 2.98 & 3.37 & 2.30 & - & - \\
\hline Phthallic acid, isobutylundecyl ester & 1109 & 1.78 & 1.51 & 6.38 & - & 2.71 \\
\hline Nerolidol & 1111 & 12.55 & 0.72 & 8.79 & - & - \\
\hline Trans-beta-Ionone & 1117 & 0.89 & 1.23 & 1.43 & - & - \\
\hline Heptadecanal & 1123 & - & 0.83 & - & - & - \\
\hline Isopropyl myristate & 1124 & - & - & - & - & 1.01 \\
\hline$\alpha$-Cardinol & 1135 & - & 1.30 & - & - & - \\
\hline Octadecane & 1138 & - & 3.55 & 3.46 & - & 0.63 \\
\hline Hexadecanoic acid, methyl ester & 1149 & 1.1 & - & - & - & - \\
\hline Benzophenone & 1154 & - & - & 2.00 & - & - \\
\hline Spathulenol & 1157 & - & 1.19 & - & - & - \\
\hline Curan-17-oic acid, 2,16-didehydro-20-hydroxy-19-oxo-, methyl ester & 1159 & - & 1.41 & - & - & - \\
\hline Methyl salicylate & 1173 & - & - & - & 5.62 & - \\
\hline n-Hexadecanoic acid & 1185 & 5.90 & 7.33 & - & - & - \\
\hline Phenanthrene & 1186 & - & - & 1.25 & - & - \\
\hline Dibutyl phthalate & 1188 & 1.51 & 5.19 & 5.19 & & 24.95 \\
\hline Hexadecanal & 1198 & 3.93 & - & - & - & - \\
\hline Phytol & 1203 & 0.81 & 2.34 & - & - & - \\
\hline Pentadecanal & 1204 & 2.71 & 4.10 & 2.04 & - & - \\
\hline Benzaldehyde, 4-methoxy & 1223 & - & - & - & 3.90 & - \\
\hline Bicyclo[10.8.0] eicosane, cis- & 1226 & 4.36 & 3.43 & - & - & - \\
\hline 1-Naphthalenamine, N-phenyl- & 1233 & 1.29 & 1.76 & 4.44 & - & - \\
\hline Eicosane & 1282 & 20.93 & 17.12 & 21.59 & - & 0.73 \\
\hline Heptacosane & 1919 & 12.04 & 9.13 & - & - & - \\
\hline 1,22-Docosanediol & 2246 & 3.85 & - & - & - & - \\
\hline 1-Ascorbic acid 2,6-dihexadecanoate & 2299 & - & 1.12 & - & - & 2.97 \\
\hline Total & & 90.35 & 78.99 & 92.77 & 96.59 & 99.99 \\
\hline
\end{tabular}

Note: RI- Retention Indices 


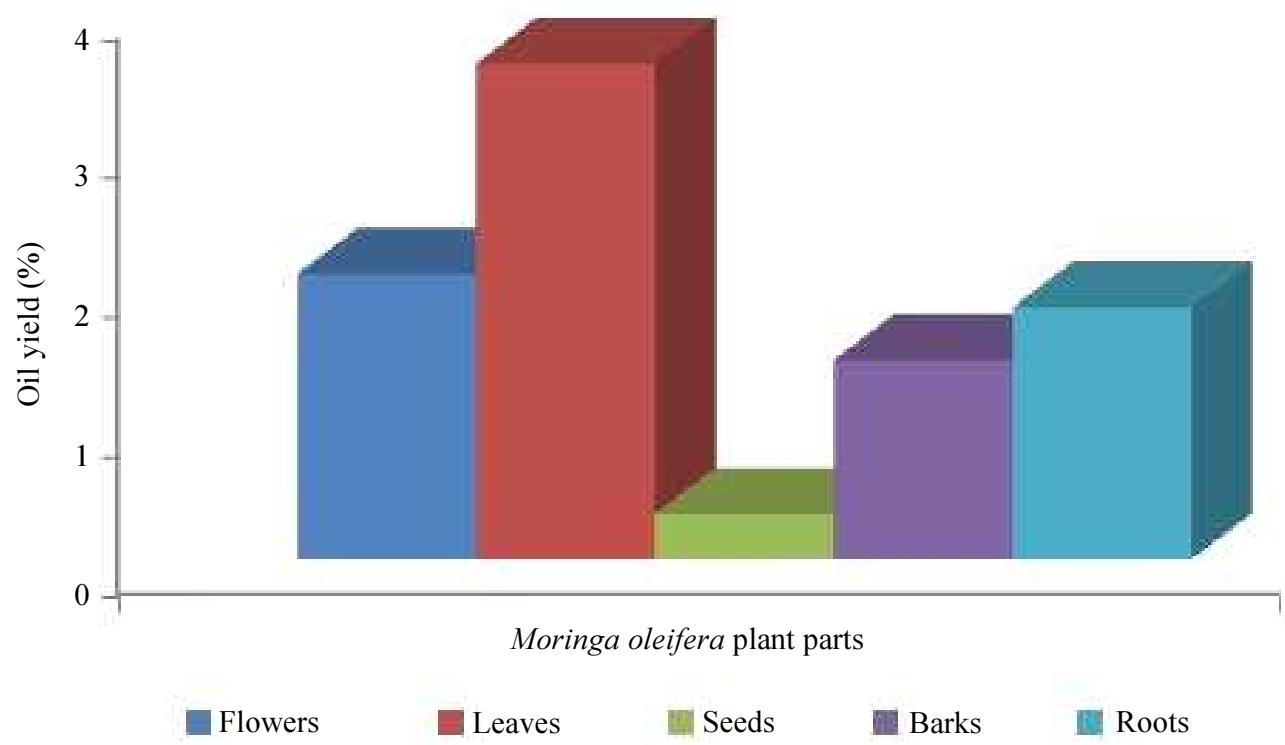

Fig. 1: Essential oil yields from the different plant parts of Moringa oleifera *Values are means $\pm \operatorname{SD}(n=3)$. Bars with different superscripts are significantly different $(\mathrm{p}<0.005)$

Table 2: Inhibition zone diameter ( $\mathrm{mm}$ ) of essential oils from the different plant parts of M. oleifera

\begin{tabular}{lcccccc}
\hline Bacterial strains & Flowers & Leaves & Seeds & Barks & Roots & Ciprofloxacin \\
\hline Gram positive & $16 \pm 1.41^{\mathrm{a}}$ & $16 \pm 2.83^{\mathrm{a}}$ & $18 \pm 1.41^{\mathrm{b}}$ & $14 \pm 0.71^{\mathrm{c}}$ & $16 \pm 2.12^{\mathrm{a}}$ & $44 \pm 2.83^{\mathrm{d}}$ \\
$\begin{array}{l}\text { Enterococcus faecalis } \\
\text { Gram negative }\end{array}$ & & & & & \\
Klebsiella pneumoniae & $19 \pm 4.24^{\mathrm{a}}$ & $25 \pm 2.83^{\mathrm{b}}$ & $17.4 \pm 0.71^{\mathrm{c}}$ & $21 \pm 9.19^{\mathrm{d}}$ & $15 \pm 2.12^{\mathrm{e}}$ & $46 \pm 2.12^{\mathrm{f}}$ \\
Proteus vulgaris & $15 \pm 2.12^{\mathrm{a}}$ & $21 \pm 2.83^{\mathrm{b}}$ & $21 \pm 4.95^{\mathrm{b}}$ & $19 \pm 2.12^{\mathrm{c}}$ & $17 \pm 1.41^{\mathrm{d}}$ & $47 \pm 1.41^{\mathrm{e}}$ \\
Shigella flexineri & $20 \pm 0.00^{\mathrm{a}}$ & $19 \pm 7.07^{\mathrm{a}}$ & $20 \pm 7.07^{\mathrm{a}}$ & $18 \pm 0.00^{\mathrm{c}}$ & $23 \pm 4.24^{\mathrm{d}}$ & $53 \pm 6.36^{\mathrm{e}}$ \\
\hline
\end{tabular}

${ }^{*}$ Values are means $\pm \mathrm{SD} ; n=3$; Means with different superscripts in the same row are significantly different $(P<0.05)$. Ciprofloxacin, reference antibiotic

Table 3: Minimum Inhibitory Concentration (MIC) of essential oils from the different plant parts of M. oleifera

\begin{tabular}{lllllll}
\hline Bacterial strain & Flower & Leaf & Seed & Bark & Root & Ciprofloxacin \\
\hline Enterococcus faecalis & $>5$ & $>5$ & 5 & 5 & $>5$ & $>5$ \\
Shigella flexineri & $>5$ & $>5$ & $>5$ & $>5$ & $>5$ & $>5$ \\
Proteus vulgaris & 1.25 & $>5$ & 5 & $>5$ & $>5$ & 5 \\
Klebsiella pneumoniae & 2.5 & 2.5 & 1.25 & $>5$ & $>5$ & 2.5
\end{tabular}

Note: MIC, Minimum Inhibitory Concentration in $\mathrm{mg} / \mathrm{mL}$

\section{Antibacterial Activity of the Essential Oils}

The result of the agar well diffusion assay and the MICs of the extracts are summarized in Tables 2 and 3. Of the 8 bacterial isolates tested, 3 gram-ve (Klebsiella pneumonia, Proteus vulgaris and Shigella flexineri) and only 1 Gram +ve (Enterococcus faecalis) exhibited susceptibility to the oils with inhibition zones ranging from 14.00 to $25.00 \mathrm{~mm}$. All the other bacterial isolates (Staphylococcus aureus, Streptococcus pyogenes, Pseudomonas aeruginosa ATCC 19582 and Serratia marcescens ATCC 9986) showed no susceptibility to any of the essential oils.
The highest antibacterial activity was observed with the leaf essential oil $(25 \mathrm{~mm})$ against $K$. pneumonia and the root oil $(23 \mathrm{~mm})$ against $S$. flexinerii respectively.

Minimum inhibitory concentration $\left(\mathrm{MIC}_{50}\right)$ for the oils (Table 3) ranged from $1.25 \mathrm{mg} / \mathrm{mL}$ for the seed oil to $>5 \mathrm{mg} / \mathrm{mL}$ in bark for $K$. pneumonia; while for $P$. vulgaris it was $1.75 \mathrm{mg} / \mathrm{ml}$ for the flower and $10 \mathrm{mg} / \mathrm{ml}$ for the leaf essential oils respectively. For both $S$. flexineri and E. faecalis, $\mathrm{MIC}_{50}$ was $>5 \mathrm{mg} / \mathrm{mL}$, while for the reference drug Ciprofloxacin, $\mathrm{MIC}_{50}$ was $>5 \mathrm{mg} / \mathrm{mL}$ for all the bacterial strains tested except for $K$. pneumoniae which was $2.5 \mathrm{mg} / \mathrm{mL}$. 


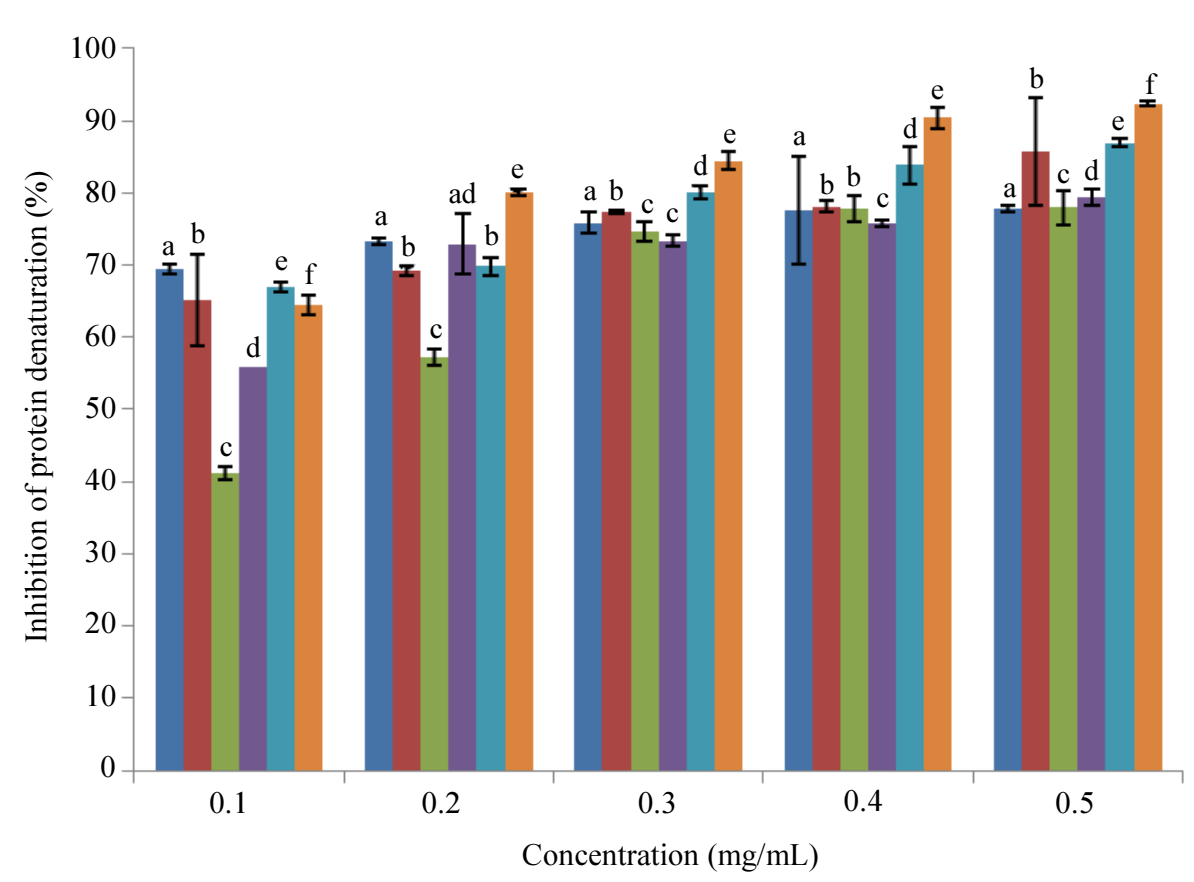

$\square$ Flowers $\square$ Leaves $\square$ Seeds $\square$ Barks $\square$ Roots $\square$ Diclofenac

(A)

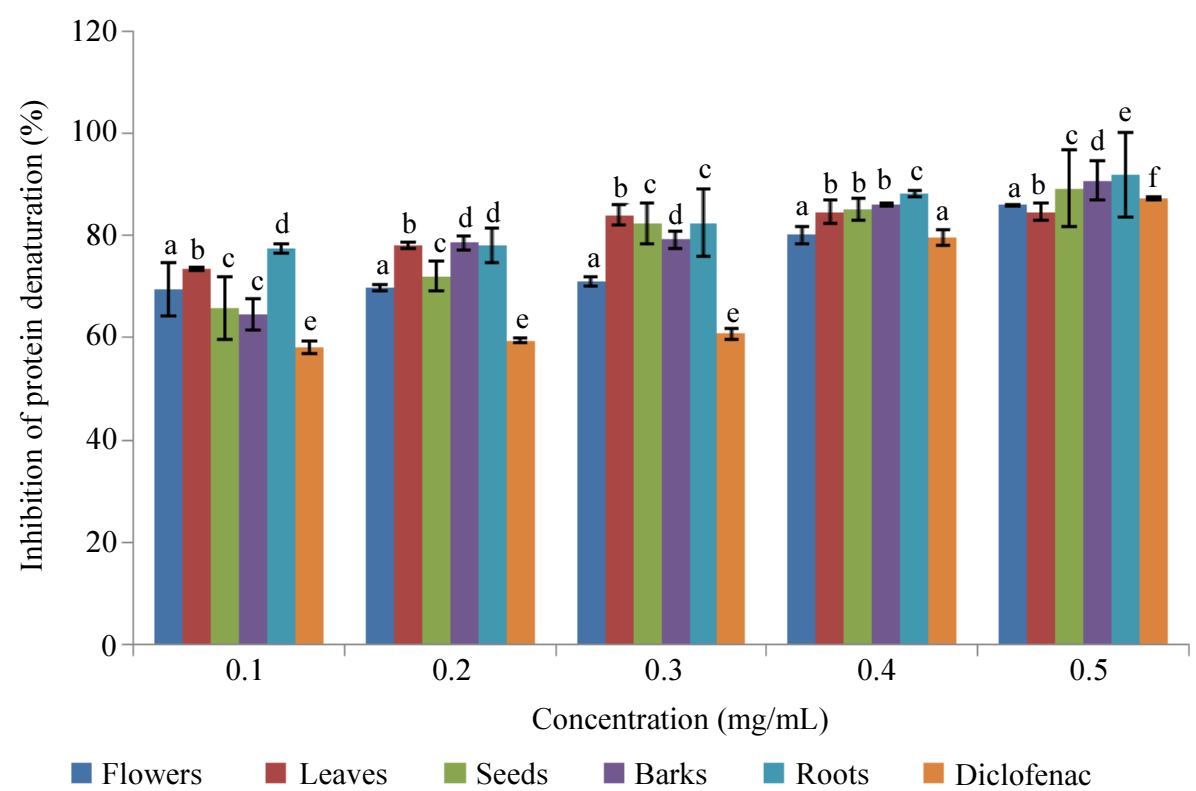

(B)

Fig. 2: Activity of essential oils extracted from the various parts of $M$. oleifera on (A) inhibition of heat induced protein denaturation and $(B)$ erythrocyte membrane stability; *Values are means \pm SD $(n=3)$. Bars within the same concentration with different superscripts are significantly different $(p<0.005)$

\section{Anti-Inflammatory Activity}

Essential oils from the different parts of $M$. oleifera showed very high $(\mathrm{p}<0.05)$ concentration-dependent inhibitory activity against protein (albumin) denaturation
(Fig. 2A). All the oils, exhibited inhibition against protein denaturation at $\mathrm{IC}_{50}<0.1 \mathrm{mg} / \mathrm{mL}$, except the leaf oil which showed a higher $\mathrm{IC}_{50}$ at $0.2 \mathrm{mg} / \mathrm{mL}$. The membrane stabilizing action of the essential oils followed the same trend as observed for protein 
denaturation (Fig. 2B). Erythrocyte membrane stability was enhanced in a concentration-dependent manner, with oil from the roots exhibiting the highest inhibition $\mathbf{( 7 7 . 5 0}$ $\%$ ) of membrane haemolysis at $\mathrm{IC}_{50}: 0.1 \mathrm{mg} / \mathrm{mL}$.

\section{Discussion}

The essential oils obtained from the different parts of M. oleifera showed variety in their composition. For instance, eucalyptol, benzene acetaldehyde, nonanal and camphor occurred in the flower, leaf, seed and bark essential oils but were absent in the root oil; while methyl eugenol, trans-beta-ionone and 1naphthalenamine, N-phenyl were present only in the flower, leaf and seed. 1-(+)- Ascorbic acid 2,6dihexadecanoate was present only in the leaf and root oils; anethole in seed and bark oils; nerolidol in flower, leaf and seed oils and phytol in flower and leaf oils alone. Only the essential oil from the bark contained Methyl salicylate while isopropyl myristate was found in the root oil alone. Interestingly, 1-(+) - Ascorbic acid 2, 6-dihexadecanoate was found to be higher $(2.97 \%)$ in the root than in the leaf $(1.12 \%)$.

Pino (2013) reported that the volatile fraction of Moringa flower essential oils was characterized by aliphatic compounds, nitrogen-compounds, oxygenated monoterpenes, monoterpene hydrocarbons and oxygenated sesquiterpenes. The presence of benzaldehyde, ionone, phytol, benzene acetaldehyde, hexacosane, pentacosane and heptacosane have also been reported (Chuang et al., 2007; Marrufo et al., 2013). According to Hussein et al. (2014), the major constituents of Moringa seed oil were naphthalene and benzene isothiocyanato methyl, while the main constituents of root oil were hydrocarbons, acids, esters, alcohols, aromatics and alkamides along with benzyl glucosinolate (Goyal et al., 2007; Faizi et al., 2014). This is similar to our findings and we also report that the main components of $M$. oleifera bark essential oil were naphthalene, nonanal, camphor and methyl salicylate.

All the different parts of $M$. oleifera essential oils showed strong broad spectrum activity against both Gram-positive and Gram-negative bacterial strains as shown by the zone inhibition diameters which were greater than $13 \mathrm{~mm}$ (Vieira et al., 2010); and the MICs. The various bioactive components of the essential oils could account for the differences observed in their antimicrobial effects.

Broad spectrum activity attributed to bactericidal substances or toxins have been reported earlier for water and ethanol-based moringa seed extracts (Vieira et al., 2010). According to Silva et al. (2011), the antimicrobial actions of essential oils are attributed mainly to phenolic compounds. The reports by Dorman and Deans (2000) that terpenes induced antimicrobial properties are corroborated by the results obtained in this study. However, other minor components such as limonene, linalool, $\gamma$-terpinene, $\mathrm{p}$ cimene, $\alpha$-pinene and $\alpha$-terpineol could be responsible for antimicrobial activity due to synergistic effects (Van Vuuren and Viljoen, 2007). This is in agreement with our findings in this study as other components such as phenols, alpha-thujone and terpinen-4-ol were present in the essential oils.

Protein denaturation is one of the main causes of inflammatory and arthritic diseases (Chatterjee et al., 2012). In this study, inhibitory actions of the essential oils on denaturation of BSA and rat erythrocyte membrane haemolysis were used to evaluate anti-inflammatory activity. Agents that could prevent protein condensation, precipitation of denatured protein aggregates and inhibit the COX enzyme or protect the lysosomal membrane from breakdown are useful in attenuating inflammation and its attendant diseases (Rauf et al., 2014; Osman et al., 2016).

Essential oils from the various parts of $M$. oleifera protected the erythrocyte membrane against lysis induced by hypotonic solution in the order root oil $>$ leaf oil $>$ flower oil $>$ seed oil $>$ bark oil $>$ Diclofenac. The ability of the essential oils to maintain erythrocyte membrane integrity was comparable and even higher than that of diclofenac the standard drug.

Because of the similarities between the erythrocyte and lysosomal membranes, prevention of the rupture of the erythrocyte membrane is an indication that such agents will protect the tissue against damage caused by the release of hydrolytic enzymes thus alleviating some symptoms of inflammation (Olajide et al., 2000; Tatiya and Saluja, 2011).

Research has shown that the main mechanisms of action of common anti-inflammatory drugs like aspirin and diclofenac is by preventing protein denaturation, enhancing membrane stability and inhibitory effect on cyclooxygenase (Umapathy et al., 2010; Odeyemi et al., 2015). The observed anti-inflammatory properties of $M$. oleifera essential oils could therefore be attributed to their capacity to inhibit thermal and hypotonic protein denaturation and enhance membrane stability. This is in agreement with reports on the aqueous, ethanol, chloroform and hydro-ethanol extracts of $M$. oleifera flower extracts (Alhakmani et al., 2013), leaves (Rao et al., 1999) and seeds (Minaiyan et al., 2014) on inflammatory models. For the first time, this study reports the anti-inflammatory effects of essential oils from $M$. oleifera parts. The observed anti-inflammatory activity could be attributed to benzene isocyanato methyl or isopropyl myristate in the root oil, methyl salicylate and alpha-thujone in the bark as well as other phytochemicals present in the various parts which can interfere with the early phase of inflammation to stop the cascade reactions (Matsuda et al., 2007; Vijayalakshmi et al., 2011). Although the mode of action is yet to be determined, it could be that the oils acted by inhibiting protein denaturation. 
Previous studies have reported organ-dependant variations and distribution of essential oil components in plants such as Conyza bonariensis L (Mabrou et al., 2011), Helichrysum armenium (Oji and Shafaghat, 2012), Ligusticopsis wallichiana (Padalia et al., 2012), Canarium parvum Leen. and Canarium tramdenanum Dai et Yakovl. (Burseracea) (Thang et al., 2014).

The results agree with reports from previous studies; for instance, Methyl Salicylate (MeSa) is an important topical analgesic and anti-inflammatory agent which acts as a counter-irritant. MeSa is the active ingredient in topical liniments and ointments used in the management of rheumatic/ arthritic conditions (Paudel et al., 2013), as a flavouring agent in foods, beverages and confectionaries (Anderson, 2003) and as an insecticidal agent (Bossou et al., 2013). Benzene, Isothiocyanato methyl (BITC), the major component of oil from Moringa root, has been established as a therapeutic agent for treating leukaemia and pancreatic cancers (Batra et al., 2010). BITC acts as an antioxidant, antiproliferative and apoptotic agent that inhibits NF- $\mathrm{B}$ binding to DNA; suppresses lipid accumulation and macrophage infiltration in tumor tissues. Previous studies have also established that BITC blocks important signaling pathways relevant to tumor progression and invasion (Rao, 2013). Megastigmatrienone, an aromatic flavor compound which produces some of the spice notes associated with certain wines is limited to the flower essential oil. Similarly, isopropyl myristate which is a good emollient used in cosmetic and medicinal preparation as a topical antifungal, anti-bacterial, anti-lice and anti-fleas was limited to the root oil alone. Alpha-Thujone present in M. oleifera bark oil has anthelmintic, anti-nociceptive and insecticidal actions (Hold et al., 2000). Bueno et al. (2011) reported that alpha cardinol; a sesquiterpene present in $M$. oleifera leaf oil, has anti-fungal, hepatoprotective properties and is a possible remedy for drug-resistant tuberculosis. The synergistic effects of these bioactive compounds in the essential oils could account for the antibacterial, antiinflammatory and other folkloric therapeutic effects attributed to the whole plant. However, there is the need for caution in the use of the roots, bark and seed oils of $M$. oleifera because of the high content of phthalate compounds.

\section{Conclusion}

The study reports for the first time the comparative chemical composition, antibacterial and antiinflammatory effects of essential oils from the flowers, leaves, seeds, barks and roots of Moringa oleifera. The presence of bioactive compounds such as benzene, isocyanato methyl and isopropyl myristate in the root oil, methyl salicylate and alpha-thujone and other phytochemicals are evidence of their potential therapeutic effects and the diverse nutritional and pharmacological uses of $M$. oleifera traditionally. The possibility of $M$. oleifera root oil as a lead for anti-cancer drug could be further explored considering the high concentration of benzene isothiocyanato methyl.

\section{Conflict of Interest}

The authors declare that they have no conflict of interest.

\section{Acknowledgement}

This work was supported by the National Research Foundation (NRF) and the Medical Research Council MRC, both of South Africa.

\section{Author's Contributions}

Gloria Aderonke Otunola: Conceptualized and designed the study, performed the experiments. Contributed equally to the writing, proof reading and approval of the final version of this manuscript.

Anthony Jide Afolayan: Participated in the concept and design of the study. Contributed equally to the writing, proof reading and approval of the final version of this manuscript.

\section{Ethics}

This article is original and contains unpublished material. The corresponding author confirms that both authors have read and approved the manuscript and there are no ethical issues involved.

\section{References}

Adams, R.P., 2007. Identification of Essential Oil Components by Gas Chromatography/Mass Spectrometry. 4th Edn., Allured Publishing Corporation, Carol Stream, IL., ISBN-10: 1932633219, pp: 804.

Alhakmani, F., S., Kumar and S.A. Khan, 2013. Estimation of total phenolic content, in-vitro antioxidant and antiinflammatory activity of flowers of Moringa oleifera. Asian Pac. J. Trop. Biomed., 3: 623-627. DOI: $10.1016 / \mathrm{S} 2221-1691(13) 60126-4$

Amrutia, J.N., M. Lala, U. Srinivasan, A.R. Shabaraya and R.S. Moses, 2011. Anticonvulsant activity of Moringa oleifera leaf. Int. Res. J. Pharm., 2: 160-162.

Anderson, F.A., 2003. Cosmetics Ingredient Review (CIR): Safety assessment of Salicylates. Int. J. Toxicol., 22: 1-108.

Bakre, A.G., A.O. Aderibigbe and O.G. Ademowo, 2013. Studies on neuropharmacological profile of ethanol extract of Moringa oleifera leaves in mice. J. Ethnopharmacol., 149: 783-789. DOI: $10.1016 /$ j.jep.2013.08.006 
Batra, S., R.P. Sahu, P.K. Kandala and S.K. Srivastava, 2010. Benzyl isothiocyanate mediated inhibition of histone deacetylase leads to NF- $\kappa \mathrm{B}$ turn-off in human pancreatic carcinoma cells. Mol. Cancer Ther., 9: 1596-1608. DOI: 10.1158/1535-7163.MCT-09-1146

Bossou, A.D., S. Mangelinckx, H. Yedomonhan, P.M. Boko and M.C. Akogbeto et al., 2013. Chemical composition and insecticidal activity of plant essential oils from Benin against Anopheles gambiae (Giles). Parasite Vectors, 6: 337-337. DOI: $10.1186 / 1756-3305-6-337$

Bueno, J., P. Escobar, J.R. Martínez, S.M. Leal and E.E. Stashenko, 2011. Composition of three essential oils and their mammalian cell toxicity and antimycobacterial activity against drug resistanttuberculosis and nontuberculous mycobacteria strains. Nat. Prod. Commun., 6: 1743-1748. PMID: 22224302

Chatterjee, P., S. Chandra, P. Dey and S. Bhattacharya, 2012. Evaluation of anti-inflammatory effects of green tea and black tea: A comparative in vitro study. J. Adv. Pharm. Technol. Res., 3: 136-138. DOI: $10.4103 / 2231-4040.97298$

Chuang, L.P.H., C.W. Lee, J.Y. Chou, M. Murugan and B.J. Shieh et al., 2007. Anti-fungal activity of crude extracts and essential oil of Moringa oleifera. Biores. Technol., 98: 232-236.

DOI: 10.1016/j.biortech.2005.11.003

Dorman, H.J.D. and S.G. Deans, 2000. Antimicrobial agents from plants: Antibacterial activity of plant volatile oils. J. Applied Microbiol., 88: 308-316. DOI: $10.1046 / \mathrm{j} .1365-2672.2000 .00969 . x$

Fahey, J.D., 2005. Moringa oleifera: A review of the medical evidence for its nutritional, therapeutic and prophylactic properties part 1. Tree Life J., 1: 5-5. DOI: $10.1201 / 9781420039078 . c h 12$

Faizi, S., S. Sumbul, M.A. Versiani, R. Saleem and A. Sana et al., 2014. GC/GCMS analysis of the petroleum ether and dichloromethane extracts of Moringa oleifera roots. Asian Pac. J. Trop. Biomed., 4: 650-654. DOI: 10.12980/APJTB.4.201414B141

Goyal, B.R., B.B. Agrawal, R.K. Goyal and A.A. Mehta, 2007. Phyto-pharmacology of Moringa oleifera Lam: An overview. Nat. Prod. Radiance, 6: 347-353. http://nopr.niscair.res.in/handle/123456789/7883

Hold, K.M., N.S. Sirisoma, T. Ikeda, T. Narahashi and J. Casida, 2000. Alpha-thujone (the active component of absinthe): Gamma-aminobutyric acid type A receptor modulation and metabolic detoxification. Proc. Natl. Acad. Sci. USA, 97: 3826-31.

DOI: $10.1073 /$ pnas.070042397

Hussein, M.A., N.A. Gobba and M.H. El Bishbishy, 2014. Composition, in vitro antioxidant and antitumor properties of essential oil from the seeds of Moringa oleifera. Int. J. Pharm. Sci., 4: 532-540.
Jabeen, R., S. Muhammad, A. Jamil and A. Muhammad, 2008. Microscopic evaluation of the antimicrobial activity of seed extracts of Moringa oleifera. Pak. J. Bot., 40: 1349-1358.

Khan, M.A., H. Khan, S.A. Tariq and S. Pervez, 2015. In vitro attenuation of thermal-induced protein denaturation by aerial parts of Artemisia scoparia. J. Evid.-Based Complement Altern. Med., 20: 9-12. DOI: $10.1177 / 2156587214548458$

Kuben, K.N. and M.C. Roger, 2011. Review on herbal remedies used by the 1860 South African Indian settlers. Afr. J. Biotechnol., 10: 8533-8538. DOI: $10.5897 / A J B 11.003$

Mabrou, S., A. Elaissi, B.H. Jannet and F. HarzallahSkhiri, 2011. Chemical composition of essential oils from leaves, stems, flower heads and roots of Conyza bonariensis L. from Tunisia. Nat. Prod. Res., 25: 77-84.

\section{DOI: $10.1080 / 14786419.2010 .513685$}

Marrufo, T., F. Nazzaro, E. Mancini, F. Fratianni and R. Coppola et al., 2013. Chemical composition and biological activity of the essential oil from leaves of Moringa oleifera lam. Cultivated Mozambique. Molecule., 18: 10989-11000.

DOI: $10.3390 /$ molecules180910989

Mahajan, S.G., R.G. Mali and A.A. Mehta, 2007. Protective effect of ethanolic extract of seeds of Moringa oleifera lam. Against inflammation associated with development of arthritis in rats. J. Immunotoxicol., 4: 39-47.

DOI: $10.1080 / 15476910601115184$

Maponga, C.C. and T.G. Monera, 2010. Moringa oleifera supplementation by patients on antiretroviral therapy. J. Int. AIDS Soc., 13: 188-188. DOI: 10.1186/1758-2652-13-S4-P188

Matsuda, H., M. Ochi, A. Nagatomo and M. Yoshikawa, 2007. Effects of allyl isothiocyanate from horseradish on several experimental gastric lesions in rats. Eur. J. Pharmacol., 561: 172-181. DOI: 10.1016/j.ejphar.2006.12.040

Minaiyan, M., G. Asghari, D. Taheri, M. Saeidi and S. Nasr-Esfahan, 2014. Anti-inflammatory effect of Moringa oleifera Lam. seeds on acetic acidinduced acute colitis in rats. Avicenna J. Phytomed., 4: 127-136. PMID: 25050310

Mishra, G., P. Singh, R. Verma, S. Kumar and S. Srivastav et al., 2011. Traditional uses, phytochemistry and pharmacological properties of Moringa oleifera plant: an overview. Der. Pharmacia Lett., 3: 141-164.

Moyo, B., P.J. Masika, A. Hugo and V. Muchenje, 2013. Nutritional characterization of Moringa (Moringa oleifera Lam.) leaves. Afr. J. Biotechnol., 10: 12925-12933. DOI: 10.5897/AJB10.1599 
Mukunzi, D., J. Nsor-Atindana, Z. Xiaoming, A. Gahungu and E. Karangwa et al., 2011. Comparison of volatile profile of Moringa oleifera leaves from Rwanda and China using HS-SPME. Pak. J. Nutr., 10: 602-608. DOI: 10.3923/pjn.2011.602.608

Murugan, R. and T. Parimelazhagan, 2014. Comparative evaluation of different extraction methods for antioxidant and anti-inflammatory properties from Osbeckia parvifolia Arn.-An in vitro approach. J. King Saudi Univ.-Sci., 26: 267-275.

DOI: $10.1016 /$ j.jksus.2013.09.006

Odeyemi, S., A.J. Afolayan and G. Bradley, 2015. In vitro anti-inflammatory and free radical scavenging activities of crude saponins extracted from Albuca bracteata Jacq. Bulb. Afr. J. Tradit. Complement Altern Med., 12: 34-40. DOI: 10.4314/ajtcam.v12i4.6

Oji, K.A. and A. Shafaghat, 2012. Constituents and antimicrobial activity of the essential oils from flower, leaf and stem of Helichrysum armenium. Nat. Prod. Commun., 7: 671-674. PMID: 22799105

Olajide, B., K. Giller, T. Teucher, B. Behnke and H. Schmitz, 2000. Anti-inflammatory effect of Urtica dioica extract in comparison to caffeic malic acid. Arzneimittelforschung, 46: 52-56. PMID: 8821518

Omale, J. and P.N. Okafor, 2008. Comparative antioxidant capacity, membrane stabilization, polyphenol composition and cytotoxicity of the leaf and stem of Cissus multistriata. Afr. J. Biotechnol., 7: 3129-3133.

Osman, N.I., N.J. Sidik, A. Awal, N.A.M. Adam and N.I. Rezali, 2016. In vitro xanthine oxidase and albumin denaturation inhibition assay of Barringtonia racemosa L. and total phenolic content analysis for potential anti-inflammatory use in gouty arthritis. J. Interc. Ethnopharmacol., 5: 343-349. DOI: $10.5455 /$ jice. 20160731025522

Otang, W.B., D.S. Grierson and R.N. Ndip, 2012. Phytochemical studies and antioxidant activity of two South African medicinal plants traditionally used for the management of opportunistic fungal infections in HIV/AIDS patients. BMC Complement Altern. Med., 12: 1-7. DOI: $10.1186 / 1472-6882-12-43$

Oyedapo, O.O., B.A. Akinpelu, K.F. Akinwunmi, M.O. Adeyinka and F.O. Sipeolu, 2010. Red blood cell membrane stabilizing potentials of extracts of Lantana camara and its fractions. Int. J. Plant Physiol. Biochem., 2: 46-51.

Padalia, R.C., R.S. Verma, A. Chauhan, Chanotiya, C.S., Yadav, A., 2012. Variation in the volatile constituents of different plant parts of Ligusticopsis wallichiana from western Himalaya, India. Nat. Prod. Commun., 7: 1077-1078. PMID: 22978233

Padmanabhan, P. and S.N. Jangle, 2012. Evaluation of in-vitro anti-inflammatory activity of herbal preparation, a combination of four medicinal plants. Int. J. Basic Applied Med. Sci., 2: 109-116.
Pandey, A., 2012. Moringa oleifera Lam. (Sahijan)-a plant with a plethora of diverse therapeutic benefits: An updated retrospection. Med. Aromatic Plant, 1: 101-101. DOI: 10.4172/2167-0412.1000101

Patel, S., A.S. Thakur, A. Chandy and A. Manigauha, 2010. Moringa oleifera: A review of their medicinal and economical importance to the health and nation. Drug Invent Today, 2: 339-342.

Paudel, P., P. Satyal, N.S. Dosoky, S. Maharjan and W.N. Setzer, 2013. Juglans regia and J. nigra, two trees important in traditional medicine: A comparison of leaf essential oil compositions and biological activities. Nat. Prod. Commun., 8: 1481-1486. PMID: 24354208

Pino, J.A., 2013. Floral scent composition of Moringa oleifera Lam. J. Essent Oil Bear. Plant, 16: 315-317. DOI: 10.1080/0972060X.2013.813189.

Price, M.L., 2007. The moringa tree. ECHO tech note. 17391. Durrance Road, North Fort Myers, FL 33917, USA.

Rao, K.N.V., V. Gopalakrishnan, V. Loganathan and S.S. Nathan, 1999. Anti inflammatory activity of Moringa oleifera Lam. Ancient Sci. Life, 18: 195-198.

Rao, C.V., 2013. Benzyl isothiocyanate: Double trouble for breast cancer cells. Cancer Prev. Res., 6: 760-760. DOI: 10.1158/1940-6207.CAPR-13-0242

Rauf, A., R. Khan, H. Khan, S. Pervez and A.S. Pirzada, 2014. In vivo antinociceptive and anti-inflammatory activities of umbelliferone isolated from Potentilla evestita. Nat. Prod. Res., 17: 1371-1374.

Silva, F., S. Ferreira, A. Duarte, D.I. Mendonca and F.C. Domingues, 2011. Antifungal activity of Coriandrum sativum essential oil, its mode of action against Candida species and potential synergism with amphotericin B. Phytomed. 19: 42-47. DOI: $10.1016 /$ j.phymed.2011.06.033

Tatiya, A.U. and A.K. Saluja, 2011. Further studies on membrane stabilizing, anti-inflammatory and FCA induced arthritic activity of various fractions of bark of Machilus macrantha in rats. Rev. Bras. Farmacogn., 21: 1052-1064. DOI: $10.1590 / \mathrm{S} 0102-695 X 2011005000152$

Thang, T.D., D.N. Dai, N.X. Luong and I.A. Ogunwande, 2014. Constituents of essential oils from the leaves, stem barks and resins of Canarium parvum Leen. and Canarium tramdenanum Dai et Yakovl. (Burseracea) grown in Vietnam. Nat. Prod. Res.: Formerly Nat. Prod. Lett., 28: 461-466. DOI: 10.1080/14786419.2013.873435

Umapathy, E., E.J. Ndebia, A. Meeme, B. Adam and P. Menziwa et al., 2010. An experimental evaluation of Albuca setosa aqueous extract on membrane stabilization, protein denaturation and white blood cell migration during acute inflammation. J. Med. Plants Res., 4: 789-795. 
Van Vuuren, S.F. and A.M. Viljoen, 2007. Antimicrobial activity of limonene enantiomers and 1, 8-cineole alone and in combination. Flavour Fragrance J., 22: 540-544. DOI: 10.1002/ffj. 1843

Vieira, G.H.F., J.A. Mourão, A.M. Angelo, R.A. Costa and R.H.S. dos Fernandes Vieira, 2010. Antibacterial effect (in vitro) of moringa oleifera and Annona muricata against gram positive and gram negative bacteria. Rev. Inst. Med. Trop. Sao Paulo, 52: 129-132.

DOI: $10.1590 / \mathrm{S} 0036-46652010000300003$
Vijayalakshmi, A., V. Ravichandiran, M. Velraj, S. Hemalatha and G. Sudharani et al., 2011. Antianaphylactic and anti-inflammatory activities of a bioactive alkaloid from the root bark of Plumeria acutifolia Poir. Asian Pacific J. Trop. Biomed., 1: 401-405. DOI: 10.1016/S2221-1691(11)60088-9

Yua, G., M.L. Wahlqvist, G. He, M. Yang and D. Li, 2006. Natural products and anti-inflammatory activity. Asia Pac. J. Clin. Nutr., 15: 143-152. PMID: 16672197 